\title{
ANALYSIS OF CAUSES OF MENORRHAGIA IN PATIENTS WITH NORMAL PELVIC PATHOLOGY
}

Shiva Kumar H. C1 ${ }^{1}$ Ramaraju H. E2

HOW TO CITE THIS ARTICLE:

Shiva Kumar H. C, Ramaraju H. E. "Analysis of Menorrhagia in Patients with Normal Pelvic Pathology". Journal of Evolution of Medical and Dental Sciences 2015; Vol. 4, Issue 87, October 29; Page: 15172-15177,

DOI: $10.14260 /$ jemds/2015/2156

ABSTRACT: OBJECTIVE: To find the incidence of systemic causes of menorrhagia with special emphasis on careful history taking, clinical examination and inclusion of simple blood tests to diagnose hemostatic disorders. METHOD: Thirty two women with menorrhagia of 15-45 years age, without any pelvic cause and treated from 1st January, 2011 to 31st December, 2011 were recruited for this study. After a detailed history and general examination all patients were subjected to blood tests for complete blood count, bleeding time, prothrombin time, activated partial thromboplastin time (aPTT) and serum T3, T4, TSH levels. Special tests were reserved, wherever applicable, to diagnose the cause of menorrhagia. Results were analyzed statistically by 2 × 2 chi square test. RESULTS: Hypothyroidism (25\%) and inherited coagulopathy (18\%) were the two most common nonpelvic causes of menorrhagia. Menorrhagia from menarche $(\mathrm{P}<0.001)$, bleeding from other sites $(\mathrm{P}=0.007)$, history of previous operative bleeding $(\mathrm{P}<0.001)$, and history of postpartum bleeding $(\mathrm{P}<0.001)$ were statistically significant in patients with underlying hemostatic disorders. CONCLUSION(S): A detailed history, clinical examination and simple blood tests can detect systemic causes of menorrhagia.

KEYWORDS: Menorrhagia, Hypothyroidism, Coagulopathy.

INTRODUCTION: Menorrhagia, defined as regular cyclical bleeding, excessive in amount ( $>80 \mathrm{~mL})$ and/or duration ( $>5$ days) is a symptom and not a disease. Specific cause of menorrhagia is identified in less than $50 \%$ of affected women. ${ }^{1}$ in majority cause lies in the pelvis and can be easily identified. However, the bleeding may be due to undiagnosed coagulation defect. ${ }^{2}$ endocrine disorder or systemic disease.

Menorrhagia may be the only clinical manifestation of an inherited bleeding disorder. Recent studies have shown that inherited bleeding disorder, especially in mild form, is the underlying cause in a large number of women with menorrhagia and the incidence may be as high as $15 \%{ }^{2}$

Menorrhagia may ultimately lead to surgery. ${ }^{3}$ therefore patient having menorrhagia without obvious pelvic pathology should be routinely studied to diagnose underlying endocrine and hemostatic disorders.

The present study was undertaken to know the incidence of different nonpelvic causes of menorrhagia and to highlight the importance of history, clinical examination and inclusion of some simple routine blood tests in our day to day practice to diagnose underlying hemostatic disorders in patients with menorrhagia.

METHODS: Two hundred and twenty six patients between the ages of 15 and 45 years attended our outpatient department from 1st January, 2011 to 31st December, 2011 complaining of menorrhagia. After history taking, clinical examination, and investigations including sonography, endometial histology, those with a pelvic pathology like fibroids, adenomyosis, tuboovarian masses, cervical or 


\section{ORIGINAL ARTICLE}

endometrial malignancy, cervical polyp, tuberculous endometritis, and intrauterine contraceptive device, and those taking anticoagulants, oral contraceptive pills, hormones and nonsteroidal antiinflammatory drugs were excluded from the study $(n=194)$.

The remaining 32 were included in this study. A detailed menstrual history and history of other bleeding symptoms like easy bruising, bleeding from other sites, and postoperative bleeding/postpartum hemorrhage (PPH) was taken. History suggestive of thyroid, renal or liver disease was also taken. Family history of bleeding disorder was recorded. A detailed general physical examination was done to look for pallor, bleeding spots, hepatosplenomegaly, and thyroid enlargement. These patients were subjected to routine tests of complete blood count, platelet count, peripheral smear, bleeding time (BT), prothrombin time (PT), and activated partial thromboplastin time (aPTT) besides estimation of serum T3,T4 and TSH.

Wherever history, clinical examination, and the above routine tests indicated underlying medical disorders, patients were referred to the department of Medicine for further evaluation and diagnosis by special tests like renal function tests, liver function tests, and bone marrow study.

The results obtained in the study were statistically analyzed using the $2 \times 2$ chi square test.

\section{RESULTS:}

Total number of menorrhagic patients with normal pelvic pathology were 32 .

\begin{tabular}{|c|c|c|}
\hline Cause & Number of Cases & Percentage \\
\hline Hypothyroidism & 8 & 25 \\
\hline Hyperthyroidism & 0 & 0 \\
\hline Idiopathic thrombocytopenic purpura & 2 & 6 \\
\hline Inherited coagulopathy & 6 & 18 \\
\hline Liver disease & 1 & 4 \\
\hline Renal disease & 0 & 0 \\
\hline No definite cause identified & 15 & 47 \\
\hline \multicolumn{2}{|c|}{ Table 1: Systemic causes of Menorrhagia } \\
\hline
\end{tabular}

Hypothyroidism was seen in $8(25 \%)$ cases whereas no cases had hyperthyroidism. Of the inherited bleeding disorders, coagulopathy was the most common cause in 6 cases (18\%). Idiopathic thrombocytopenic purpura (ITP), renal disease, and liver disease were other causes. However, in $15(47 \%)$ cases history, clinical examination, and laboratory tests could not reveal any definite cause for menorrhagia.

\begin{tabular}{|c|c|c|c|}
\hline \multirow{2}{*}{ Cause } & & Age (years) & \\
\cline { 2 - 4 } & $\mathbf{1 5 - 2 5}$ & $\mathbf{2 6 - 3 5}$ & $\mathbf{3 6 - 4 5}$ \\
\hline Hypothyroidism & 1 & 2 & 5 \\
\hline Hyperthyroidism & 0 & 0 & 0 \\
\hline Idiopathic thrombocytopenic purpura & 1 & 1 & 0 \\
\hline Inherited coagulopathy & 4 & 2 & 0 \\
\hline Liver disease & 0 & 1 & 0 \\
\hline Renal disease & 0 & 0 & 0 \\
\hline Table 2: Age distribution of Systemic causes of Menorrhagia \\
\hline
\end{tabular}




\section{ORIGINAL ARTICLE}

Hypothyroidism was commoner in the older age group (36-45 years) whereas inherited Coagulopathy was commoner in young patients (15-25 years).

\begin{tabular}{|c|c|c|}
\hline Variable & $\begin{array}{l}\text { Patients with } \\
\text { Hemostatic } \\
\text { Disorder (8) }\end{array}$ & $\begin{array}{c}\text { Patients without } \\
\text { Hemostatic Disorder (24) }\end{array}$ \\
\hline $\begin{array}{l}\text { Duration of menorrhagia } \\
\text { Since menarche }\end{array}$ & $5(62.5 \%)$ & $2(8.33 \%)$ \\
\hline $\begin{array}{c}\text { Duration of menorrhagia } \\
\text { more than } 2 \text { years }\end{array}$ & $2(25 \%)$ & $8(33.33 \%)$ \\
\hline $\begin{array}{c}\text { Duration of menorrhagia } \\
\text { less than } 2 \text { years }\end{array}$ & $1(12.5 \%)$ & $14(58.33 \%)$ \\
\hline $\begin{array}{c}\text { Family history of bleeding } \\
\text { disorders }\end{array}$ & $3(37.5 \%)$ & $2(8.33 \%)$ \\
\hline $\begin{array}{c}\text { History of other bleeding } \\
\text { symptoms } \\
\text { \{gum/nose bleeding, Bruising }\end{array}$ & $5(62.5 \%)$ & $1(4.16 \%)$ \\
\hline Postoperative bleeding * & $2 / 5(40 \%)$ & $3 / 11(27.27 \%)$ \\
\hline Postpartum bleeding * & $1 / 3(33.33 \%)$ & $2 / 14(14.28 \%)$ \\
\hline \multicolumn{3}{|l|}{ Hemoglobin level } \\
\hline$<6 \mathrm{~g} / \mathrm{dL}$ & $3(37.5 \%)$ & $4(16.66 \%)$ \\
\hline $6-10 \mathrm{~g} / \mathrm{dL}$ & $1(12.5 \%)$ & $11(45.83 \%)$ \\
\hline$>10 \mathrm{~g} / \mathrm{dL}$ & $4(50 \%)$ & $9(37.5 \%)$ \\
\hline $\begin{array}{r}\text { Table } 3 \text { : Comparative study } \\
\text { bleeding symptoms, postopera } \\
\text { among those with hemostatic di } \\
\text { no }\end{array}$ & derlying diso & $\begin{array}{l}\text { history, history of other } \\
\text { ing, and hemoglobin level } \\
\text { bathy + ITP) and those with }\end{array}$ \\
\hline
\end{tabular}

*Percentage of women who had procedure or an event.

Menorrhagia since menarche was seen in $62.50 \%$ of those with such disorders but only in $8.33 \%$ of those without such disorder, which is highly significant $(\mathrm{P}<0.001)$. Menorrhagia of less than 2 years was significantly less $(\mathrm{P}=0.026)$ in patients with hemostatic disorders. Family history of bleeding disorder were present in those with the hemostatic disorder in $37.5 \%$ but only in $8.33 \%$ of those without it $(\mathrm{P}=0.28)$.

History of other bleeding symptoms were present in those with the disorder in $62.5 \%$ but only in $4.16 \%$ of those without it $(\mathrm{P}=0.007) .5$ out of 8patients with hemostatic disorder gave previous history of operation, out of whom two (40\%) had an episode of excessive postoperative bleeding, whereas similar episode was experienced by $27.27 \%$ (3/11) of women without hemostatic disorder $(\mathrm{P}<0.001)$.

3 of 8 patients with hemostatic disorder had history of delivery of whom 2(66.66\%) had an episode of PPH. This was higher $(\mathrm{P}<0.001)$ than $14.28 \%(2 / 14)$ of those without hemostatic disorder. Severe anemia $(\mathrm{Hb}<6 \mathrm{~g} / \mathrm{dL})$ was seen in $37.5 \%$ with hemostatic disorder in comparison to $16.66 \%$ in those without $(\mathrm{P}=0.362)$. 


\section{ORIGINAL ARTICLE}

\begin{tabular}{|c|c|c|}
\hline Laboratory values & Significance & $\begin{array}{c}\text { No. of patients } \\
\text { (n=28) a }\end{array}$ \\
\hline T3, T4 - normal, TSH - High & Hypothyroidism & 3 \\
\hline T3, T4 - low, TSH - High & Hypothyroidism & 5 \\
\hline T3, T4 - high, TSH - Low & Hyperthyroidism & 0 \\
\hline $\begin{array}{c}\text { Prolonged BT, normal aPTT, } \\
\text { thrombocytopenia }\end{array}$ & ITP & 6 \\
\hline $\begin{array}{c}\text { Prolonged BT, prolonged aPTT, } \\
\text { normal platelet count }\end{array}$ & Inherited coagulopathy & 1 \\
\hline $\begin{array}{c}\text { Prolonged PT with altered LFT, } \\
\text { thrombocytopenia }\end{array}$ & Liver disease & 0 \\
\hline $\begin{array}{c}\text { Thrombocytopenia, slightly } \\
\text { prolonged BT, }\end{array}$ & Renal disease & 2 \\
\hline \multicolumn{2}{|c|}{ Table 4: Significance of different laboratory tests performed } \\
\hline
\end{tabular}

DISCUSSION: Hypothyroidism (25\%) and inherited coagulopathy (18\%) were the two most important systemic causes of menorrhagia in our study. $62.5 \%$ of hypothyroid patients were in the age group of 36-45 years. According to Doifode and Fernandez. ${ }^{4}$ menorrhagia is the most common menstrual irregularity is hypothyroid women. T3, T4, TSH estimation should be made mandatory in cases of dysfunctional uterine bleeding to detect apparent and occult hypothyroidism. ${ }^{4}$

In studies by Trasi et al. ${ }^{5}$ Kadir et al ${ }^{1}$ and Gursel et al. ${ }^{2}$ inherited coagulopathy accounted for $19.16 \%, 17 \%$ and $15 \%$ of cases of menorrhagia respectively. This is similar to our result of $18 \%$. Menorrhagia since menarche $(62.5 \%)$ was significantly higher $(\mathrm{P}<0.001)$ in patients with hemostatic disorder. Similar results were noted by Ragni et al. ${ }^{6}(53.1 \%)$ and Kadir et al. ${ }^{1}(65 \%)$ in their studies of menorrhagic women with coagulation disorders.

The bleeding symptoms like nose or gum bleeding and bruising and was significantly higher $(\mathrm{P}=0.007)$ in those with hemostatic disorder, consistent with the findings of Kadir et al. ${ }^{1}$ Similar to the findings of Kadir et al. ${ }^{1}$ our study also revealed that history of post-operative bleeding and of postpartum bleeding were significantly more $(\mathrm{P}<0.001$ each of the two) in those with underlying hemostatic disorder. However, though family history and severe anemia were more common in women with hemostatic disorder it was not statistically significant.

Prolonged BT and aPTT with normal platelet count were stamped as cases of inherited coagulopathy. Tests to diagnose von Willebrand's disease were suggested, this being the most common coagulopathy in menorrhagic patients. ${ }^{7}$ but no patient could afford them. Wherever history, clinical examination, and routine tests indicated medical disorder, patients were referred to department of medicine to carry out special tests which helped us to diagnose different causes as shown in Table 4.

Menorrhagia since menarche, history of bleeding from other sites, postoperative bleeding, and postpartum haemorrhage fulfill the criteria required to be declared as effective diagnostic criteria, even in a comparatively small population of study. No definite cause was found in $47 \%$ cases which may be due to some hemostatic imbalance in the endometrium. 


\section{ORIGINAL ARTICLE}

Menorrhagia may be the first and only clinical manifestation of an inherited bleeding disorder. ${ }^{8}$ But coagulopathies are not considered as etiology of menorrhagia by gynecologists and unintentional surgical intervention is done without getting the patients investigated for coagulopathies. ${ }^{9}$

Our study emphasizes the importance of careful history taking since certain factors significantly predict menorrhagia viz., menorrhagia since menarche, presence of other bleeding symptoms like bruising, epistaxis, gum bleeding and history of postoperative bleeding and postpartum hemorrhage.

Clinical suspicion for an underlying bleeding disorder in menorrhagic patients will not only help in its early diagnosis but will also have important implications in management of antepartum and postpartum hemorrhage of future pregnancies. ${ }^{9}$

This study shows that search for systemic diseases including endocrine and hemostatic disorders in menorrhagic patients with no pelvic cause reveals the underlying cause in most cases.

CONCLUSION: A gynecologist's awareness and inclusion of detailed history, clinical examination and simple laboratory tests in day-today practice can prevent unnecessary hysterectomies in women with menorrhagia.

\section{REFERENCES:}

1. Kadir RA, Economides DL, Sabin CA et al. Frequency of inherited bleeding disorders in women with menorrhagia. Lancet 1998; 351:485-9.

2. Gursel T, Biri A, Kaya Z, Sivasloglu S, Albayrak M. The frequency of menorrhagia and bleeding disorders in university students. Pediatr Hematol Oncol. 2014 Aug; 31(5):467-74. doi: 10.3109/08880018.2014.886316. Epub 2014 Mar 31.

3. Fender GRK, Prentice A, Nixon RM et al. Management of menorrhagia: an audit of practices in the Anglia menorrhagia education study. BMJ 2001; 322:523-4.

4. Doifode CD, Fernandes K. Study of thyroid dysfunction in patients with dysfunctional uterine bleeding. J Obstet Gynecol India 2001; 51:93-5.

5. Trasi SA, Pathare AV, Shetty SD et al. The spectrum of bleeding disorders in women with menorrhagia: a report from Western India.Ann Hematol 2005; 84:339-42.

6. Ragni MV, Bontempo FA, Hassett AC. von Willebrand disease and bleeding in women. Haemophilia 1999; 5:313-7.

7. Kujovich JL, von Willebrand's disease and menorrhagia: prevalence, diagnosis, and management. American Journal of Hematol. 2005 Jul; 79(3):220-8.

8. Chi C1, Pollard D, Tuddenham EG, Kadir RA. Menorrhagia in adolescents with inherited bleeding disorders. J Pediatr Adolesc Gynecol. 2010 Aug; 23(4):215-22. doi: 10.1016/j.jpag.2009.11.008. Epub 2010 May 14.

9. Sethi P, Sharma A, Manhas K. Blood coagulation profile and fibrinolysis in patients with menorrhagia. Asian J Obstet Gynaecol Pract 2001; 5:43-6. 


\section{ORIGINAL ARTICLE}

\section{AUTHORS:}

1. Shiva Kumar H. C.

2. Rama Raju H. E.

\section{PARTICULARS OF CONTRIBUTORS:}

1. Assistant Professor, Department of Obstetrics and Gynaecology, Vijayanagara Institute of Medical Sciences, Bellary.

2. Assistant Professor, Department of Obstetrics and Gynaecology, Vijayanagara Institute of Medical Sciences, Bellary.

FINANCIAL OR OTHER COMPETING INTERESTS: None

\section{NAME ADDRESS EMAIL ID OF THE}

\section{CORRESPONDING AUTHOR:}

Dr. Shiva Kumar H. C,

Plot No. 48, Ward No. 31,

West $2^{\text {nd }}$ Cross,

Soudaghar Colony,

Bellary-583104.

E-mail: dr.hcshivkumar@gmail.com

Date of Submission: 05/10/2015.

Date of Peer Review: 06/10/2015.

Date of Acceptance: 17/10/2015.

Date of Publishing: 28/10/2015. 